Article

\title{
Effects of Cover Cropping on Microbial Communities Associated with Heterodera schachtii and Nematode Virulence
}

\author{
Rasha Haj Nuaima ${ }^{1,2}$, Holger Heuer ${ }^{1}\left(\mathbb{D}\right.$ and Andreas Westphal ${ }^{3, *}$ \\ 1 Julius Kühn-Institut, Institute of Epidemiology and Pathogen Diagnostics, 38104 Braunschweig, Germany; \\ rasha.haj-nuaima@julius-kuehn.de (R.H.N.); holger.heuer@julius-kuehn.de (H.H.) \\ 2 Department of Plant Protection, Faculty of Agriculture, Euphrates University, Dayr az Zawr, Syria \\ 3 Department of Nematology, University of California Riverside, Kearney Agricultural Research and \\ Extension Center, Parlier, CA 93648, USA \\ * Correspondence: andreas.westphal@ucr.edu
}

Received: 3 June 2019; Accepted: 7 October 2019; Published: 11 October 2019

\begin{abstract}
Nematode-resistant cover crops can suppress populations of plant-parasitic nematodes. Samples of a loamy and a sandy loam soil were collected from two sugar beet fields in Lower Saxonia, northern Germany ("Jeinsen" and "Gross Munzel") to measure the effects of cover cropping on the population genetic structure and infectivity of Heterodera schachtii as well as the composition of soil microbial communities. These fields allowed for a comparison of cover cropping with Brassica species resistant to Heterodera schachtii to fallow. In a series of radish bioassays with $H$. schachtii populations from Jeinsen and Gross Munzel, ratios of second-stage juveniles in roots per eggs in soil were higher in soil from under Brassica cropping than from under fallow. In denaturing gradient gelelectrophoresis, profiles of the parasitism gene vap1 differed between Brassica and fallow treatments in both populations. At Gross Munzel, microbes of soils and within nematode cysts differed between Brassica and fallow areas. Specifically, the frequency and occurrence of isolates of Pochonia chlamydosporia and Exophiala salmonis were lower within the cysts from Brassica than from fallow treatments. Overall, cover cropping with resistant Brassica species affected the bacteria and fungi infecting the cysts and subsequently, the infectivity of the $H$. schachtii population. Cover crop effects on nematode virulence (vap1 gene) and microbial colonization of the cysts could affect long-term nematode population dynamics.
\end{abstract}

Keywords: Brassica cover cropping; fallow; H. schachtii; microbial community infecting cysts; molecular assay; radish bioassay; vap1

\section{Introduction}

Heterodera schachtii is one of the most important pests of sugar beet, and has been the subject of intensive investigations for over 150 years [1]. The lemon-shaped cyst of $H$. schachtii contains the primary inoculum of up to 600 nematode eggs with the contained second-stage juvenile (J2). Spontaneously or stimulated by root exudates, J2 hatch from the eggs and move through the soil to infect host plant roots. In roots, nematodes become sedentary, and develop into adults after several molts.

Management of $H$. schachtii relies on a wide rotation of host crops with non-hosts, cover cropping with resistant hosts, and cultivating resistant or tolerant sugar beet cultivars. Other management tactics (e.g., application of granular nematicides) lack economic feasibility or are not registered. For example, the soil fumigant 1,3-dichloropropene has been banned in Germany since 1990. Cropping nematode-resistant trap crops in the year prior to sugar beet such as white mustard 
(Sinapis alba L.) or oilseed radish (Radish sativus L.) has been pivotal for nematode suppression for the last three decades, particularly in Germany, Northern Italy, and for some time in North America [2-4]. These resistant catch crops stimulate J2 infection but do not permit nematode reproduction, and thus may reduce soil population densities up to 70\% [2]. This beneficial reduction of nematode numbers reduces nematode infections in sugar beet in the following year, and thus protects yields. Cropping of resistant cultivars is challenged by a yield penalty compared to high-yielding standard cultivars in non-infested fields [5]. Tolerant cultivars have been introduced and may produce normal yields in $H$. schachtii-infested fields [6]. However, at very high nematode infestation levels, even tolerant sugar beet cultivars may be damaged by H. schachtii (Andreas Westphal, unpublished data), so there is an ongoing need for comprehensive nematode management practices, even when tolerant sugar beet cultivars are planted.

$H$. schachtii is exposed to many microbes in the complex soil environment. A better understanding of the tri-trophic interactions among plant, antagonists, and nematodes may be essential to optimize biological control. In a survey for soil suppressiveness against $H$. schachtii in California, no single predictor for soil suppressiveness against cyst nematodes was identified [7]. Soil suppressiveness was found in various soil texture classes indicating the broad utility of natural mechanisms for diminishing population densities of soil-borne plant-parasitic nematodes. Levels of soil suppressiveness varied by depth in one study in California [8]. Differences between 0-30 cm and 30-60 cm depths depended on the sequence of the fallow period and crop histories. During the fallow period, the soil water potential in the upper soil layer fell below the wilting point of plants and thus may have decreased the hatching of eggs and the activity of egg parasites in the 0-30 cm soil depth. In contrast, higher soil water potential at a 30-60 cm depth probably did not restrict the hatch from eggs [8].

The biological nature of suppressive soil against $H$. schachtii has been reported repeatedly [9-11]. In field 9E at the Agricultural Operations of the University of California Riverside, initially high population densities of $H$. schachtii caused serious stand and yield losses, but then cyst nematode population densities declined after continuous cropping of various host plants. Elimination of the suppressiveness by fumigants and biocidal treatments, and the ability to transfer this biological soil suppressiveness to conducive soil corroborated the biological nature of this phenomenon [11,12]. In additional investigations, the most common fungi isolated from infected cysts were Fusarium oxysporum, Fusarium sp. nov., Dactylella oviparasitica, and Paecilomyces lilacinus [13]. Manipulation of the soil environment can support the antagonistic potential to regulate the plant-parasitic nematode population [14]. For example, the efficacy of antagonists to the cereal cyst nematode increased more under susceptible than resistant cereal crops [15]. Additionally, the plant species influences the $H$. schachtii population densities, resulting in variability during different non-host cropping or fallow periods $[8,16]$. With Brassica cover crops, efficacy of the resistant crop can be impacted by soil suppressiveness and general cropping conditions. For example, in field and lathhouse studies with the $9 \mathrm{E}$ suppressive soil in southern California, nematode population densities declined in a lathhouse experiment. In contrast, in a field trial where winter cover crop periods were exposed to lower soil temperatures, a decline of nematode population densities was only found under the longer lasting sugar beet [17].

Cover cropping may support the natural suppressive mechanisms in the soil, but may also deter such mechanisms. For example, in a comparison of a fallow period and non-host cover crop treatments in Meloidogyne, more endospores of the obligate parasite Pasteuria penetrans developed when nematode-susceptible winter cover crops were grown $[18,19]$. In contrast, in H. schachtii the egg parasitism was decidedly decreased by mustard and oil radish cruciferous cover crops, but no such effect on parasitism was detected under rape cover crop [20]. Consequently, conserving natural mechanisms suppressing the pathogens requires selecting the right rotation crop [21].

Resistant cultivars of cover crops may alter gene frequencies of the beet cyst nematode $H$. schachtii, thereby jeopardizing the longevity of this technique [22]. H. schachtii has a high genetic diversity and the ability to overcome resistance in sugar beet after a limited number of selection cycles $[6,23,24]$. 
Furthermore, sugar beet cultivars and crop rotations shape the genetic variation of $H$. schachtii within and among sugar beet areas [25]. Therefore, selecting an efficient crop rotation is important to preserve the plant resistance.

Cover cropping with Brassica H. schachtii-resistant cover crops is standard practice in high-intensity sugar beet producing areas. Here, the hypothesis was tested that such cover cropping alters soil suppressiveness to $H$. schachtii and the genetic population structure of the nematode at different soil depths. To test this, effects of Brassica cover crops on the microbial communities associated with the cysts and soil were compared to those in fallow plots. The suppressiveness at various soil depths was compared for soil, organic matter, and cyst-inhabiting microbes. In parallel, virulence patterns of the cyst nematode exposed to the soil environments were examined. A radish bioassay, previously used to measure soil suppressiveness, was used to characterize nematode infectivity, and was followed by molecular assays to (a) examine the variation of the vap1 gene of $H$. schachtii in field-derived cysts, (b) analyze the soil bacterial and fungal communities, and (c) determine the frequency of microbial communities infecting the cysts of the field populations.

\section{Materials and Methods}

Soil samples were collected from two different fields of similar soil type. One field was located near Jeinsen, the other one was at Gross Munzel (both in Lower Saxony, Germany).

\subsection{Collections from Field Experiments at Jeinsen and Gross Munzel}

\subsubsection{Jeinsen}

In 2012, soil samples were collected from a commercial sugar beet field of a 3-year crop rotation. The soil had a loamy texture with $\mathrm{pH} 6.7$ and organic matter content of $2 \%$. The soil type was a para brown soil as described in the soil map [26]. Such soil type is typically fine textured, and is characterized by clay displacement from shallower soil layers to deeper horizons. These deep-rooting soils are frequently used for sugar beet production. In 2012, the year of sugar beet production, samples were collected from two treatments that had been applied in the stubble phase of cereal after harvest until the fall tillage in the prior year. Treatments had been established as strips: (1) fallow: one pass of tillage after the cereal harvest in August 2011, then fallow, and (2) cover crop of resistant oilseed radish Raphanus sativus 'Colonel' that was planted on 16 August 2011 at a planting density of $25 \mathrm{~kg} / \mathrm{ha}$, and cultivated until the end of November. In April, the entire experiment was planted with the tolerant sugar beet Beta vulgaris 'Pauletta'. In April and October, four replicate plots $(20 \mathrm{~m} \times 5.25 \mathrm{~m})$ were delineated in the two different treatment areas at neighboring locations, and used for soil sampling. Data of these plots were only compared by non-parametric analysis because their arrangement was predetermined by the cover crop strips. At spring sampling, after sowing the sugar beet on 23 March 2012, soil cores $0-60 \mathrm{~cm}$ deep were removed with a soil probe from each plot, and composited for 0-30 cm and 30-60 cm depths. Samples were passed through a coarse aperture sieve and mixed thoroughly. These samples were then used for population density determination after cyst extraction and for a radish bioassay (described below).

At sugar beet harvest of the field plots in October 2012, soil cores 0-30 cm deep were collected, and processed similarly as in spring from both treatments, but each sample was only divided into three subsamples (50 $\mathrm{g}$ dry soil) for cyst extraction and three for the radish bioassay. In the field, sugar beet taproots were collected from three rows $\left(10.5 \mathrm{~m}^{2}\right)$ of each of the plots. White sugar content and other chemicals (potassium, sodium, and amino nitrogen) of the sugar beet taproots were determined by a commercial laboratory through standard procedures (Qualität der Zuckerrübe, KWS, Germany). Biomass, sugar yields, extraction-inhibiting compounds, and white sugar yields were calculated following standard procedures. 


\subsubsection{Gross Munzel}

In September 2014 in the year prior to sugar beet production, field plots of a strip plot trial of fallow period treatments were used for soil sampling. The soil had a sandy loam texture with $\mathrm{pH}$ 7.5 and organic matter content of $1.5 \%$. The soil type was a para brown soil [26]. The field was cropped in a 3-year rotation of winter wheat-winter wheat-summer cover crop (Brassica)-sugar beet, or winter wheat-winter wheat, summer fallow-sugar beet. The cover crops (oilseed radish or mustard) were planted on 21 August 2014 at a planting density of $20 \mathrm{~kg} / \mathrm{ha}$. Soil samples were taken from the existing stands of oilseed radish and mustard in September. Eight plots of $10 \mathrm{~m} \times 6 \mathrm{~m}$ were established in each treatment area, in a representative horizontal design throughout the treatment strips. Soil cores 0-30 cm deep were collected with a soil probe from plots of the following treatments: (a) oilseed radish 'Defender', (b) yellow mustard Sinapis alba 'Master', and (c) fallow without ground cover.

\subsection{Soil Processing and Radish Bioassay}

\subsubsection{Cyst Extraction}

Unless otherwise noted, each composite sample was divided into twelve subsamples equivalent to $50 \mathrm{~g}$ dry soil each. Three subsamples were used for cyst extraction by density centrifugation [27]. Single soil samples (50 g) were placed in a bucket with a $250-\mu \mathrm{m}$ aperture sieve as the bottom to wash off fine soil particles with tap water. The material remaining on the sieve was suspended in water and amended with kaolin in centrifuge containers, and centrifuged at $1800 \times g$ for five minutes. After centrifugation, the supernatant was decanted into a $100-\mu \mathrm{m}$ aperture sieve to collect the not fully-filled cysts. The pellet was re-suspended in $\mathrm{MgSO}_{4}$ solution with a density of 1.28 at $1800 \times g$ for $5 \mathrm{~min}$. The supernatant was passed through the $100-\mu \mathrm{m}$ aperture sieve to collect all cysts from the sample for transfer into a tissue grinder with the appropriate clearance to disrupt the cysts within $15 \mathrm{~s}$. The water suspension of broken cysts was transferred into a measuring cylinder, and kept at $4{ }^{\circ} \mathrm{C}$ until $2 \mathrm{~mL}$ aliquots were used for counting the eggs. The mean numbers of eggs were calculated and reported per $50 \mathrm{~g}$ sample.

\subsubsection{Radish Bioassay}

A published radish bioassay that had been originally designed to determine soil suppressiveness to $H$. schachtii by measuring nematode infection when exposed to conducive or suppressive soil environments [28] was modified for the current purpose. In this assay, soils were placed in containers, and adjusted to uniform moisture among the soils to be compared. One seed of radish $R$. sativus 'Saxa $3^{\prime}$ was carefully placed $0.4 \mathrm{~cm}$ deep centrally into the soil columns. Vials were arranged in an environmental growth chamber at $28 / 23^{\circ} \mathrm{C}$ for a $16 / 8 \mathrm{~h}$ day/night cycle. After four days of incubation, the radish seedlings were harvested. Radish roots were recovered from the vials, separated from the tops, washed, cleared by diluted commercial bleach solution $(0.7 \% \mathrm{NaOCl})$ for $3 \mathrm{~min}$, stained in acid fuchsin solution, and boiled for $20 \mathrm{~s}[28,29]$. Then, nematodes were counted within the roots. Root penetration adjusted by egg density in soil indicated the infection success of $H$. schachtii $\mathrm{J} 2$ contained in the different soil environments. In the current project, nine subsamples (50 $\mathrm{g}$ dried soil-equivalent each) per each plot and depth were used for this radish bioassay in an environmental growth chamber to measure infective J2 stage of $H$. schachtii [29]. This included soils from Jeinsen collected from two depths in spring, one depth in the fall, and soils from one depth in the fall from Gross Munzel. Three groups of three subsamples each were used: (a) field soil, (b) field-derived cysts added to a loess soil substrate, and (c) field-derived cysts and organic materials added to a loess soil substrate. The radish bioassays with loess substrates were conducted to determine the effect of microbes colonizing the cysts or those growing on the organic matter. For (a), the original field samples were processed according to the published protocol. For (b) and (c), cysts and the concomitant organic matter were extracted from a $50 \mathrm{~g}$ equivalent following the methods by Müller [27], and collected on filter paper. For (b), only cysts were hand-picked and added to underground loess, presumably free of plant-parasitic nematodes. For (c), the filter paper was lined with porous plastic film to allow for the 
easy transfer of the extract including cysts and organic matter to the underground loess. All treatments were established in sealable glass vials $(250 \mathrm{~mL}$ ) containing the equivalent of $50 \mathrm{~g}$ dry soil, and were amended to a total moisture content of $22 \%$ by adding up to $11 \mathrm{~mL}$ of water.

\subsection{Molecular Assays for Genetic Characterization of H. schachtii Populations and Analysis of Microbial Communities of Soil and Cysts}

2.3.1. Genetic Characterization of H. schachtii Populations from Jeinsen and Gross Munzel Using PCR-DGGE Fingerprinting of the Effector Gene vap1

From each of the four plots per treatment at Jeinsen, 60 cysts were collected once from the spring sampling and twice from the fall sampling, and transferred into $1.5 \mathrm{~mL}$ tubes containing $50 \mu \mathrm{L}$ water and squashed with a micro pestle for subsequent DNA extraction.

For populations from Gross Munzel, ten cysts collected from each soil sample (eight samples per treatment) were pooled, except for one sample from the fallow treatment that was devoid of cysts. The cysts that were pooled per field plot origin were transferred into $1.5 \mathrm{~mL}$ tubes containing $30 \mu \mathrm{L}$ water where they were squashed with a micro pestle for subsequent DNA extraction.

DNA was extracted from the pooled cysts using the lysis buffer method [23]. In brief, the volume of the lysis buffer was added to one volume of the prepared nematode suspension, and then incubated at $66^{\circ} \mathrm{C}$ and $100{ }^{\circ} \mathrm{C}$ for two hours and $5 \mathrm{~min}$, respectively. Samples were centrifuged for $2 \mathrm{~min}$ at $15,700 \times g$ after each incubation.

The PCR-amplification of the effector gene vap 1 from the nematode DNA was conducted using the primer pair HSvap244f/HSvap548r designed to amplify vap1 fragments of approximately $365 \mathrm{bp}$ from the genomic DNA of H. schachtii populations [23]. The conditions for PCR reaction used the published protocol.

The denaturing gradient gel electrophoresis (DGGE) analysis of the vap1 gene was performed using polyacrylamide gels containing a gradient of 23 to $58 \%$. By applying the INGENY PhorU2 system (Ingeny, Goes, The Netherlands), the DGGE gels were casted [23]. The DGGE profiles were visualized by silver staining by consecutively fixing (the main components: acetic acid and ethanol), staining (silver nitrate), developing (sodium hydroxide and formaldehyde), stopping development (sodium carbonate), and conserving (glycerin and ethanol) [30].

\subsubsection{Analyzing the Soil Bacterial and Fungal Communities at Gross Munzel}

DNA was extracted from $0.5 \mathrm{~g}$ soil per replicate sample using the FastDNA SPIN Kit for soil and purified using the GENECLEAN SPIN Kit according to the manufacturer's protocol (MP Biomedicals, Santa Ana, CA, USA).

For amplification of bacterial $16 \mathrm{~S}$ rRNA gene fragments, a nested PCR was conducted in two steps, first using the two primers: U8-27 (5'-AGA GTT TGA TC (A/C) TGG CTC AG) and R1494-1514 (5' -CTA CGG (T/C) TAC CTT GTT ACG AC), flanking the 16S rRNA gene fragments for a PCR-amplicon of approximately $1506 \mathrm{bp}$. The reaction was conducted in a $25 \mu \mathrm{L}$ volume containing $1 \mu \mathrm{L}$ of the 25 -fold diluted DNA extract, $10 \times$ TrueStart Puffer, $0.2 \mu \mathrm{M}$ dNTPs, $3.75 \mathrm{mM} \mathrm{MgCl}_{2}, 0.1 \mathrm{mg} / \mathrm{mL}$ BSA (bovine serum albumin), $5 \%$ DMSO, $0.2 \mu \mathrm{M}$ of each primer, and $0.6 \mathrm{U}$ TrueStart-Taq DNA polymerase (Thermo Fisher Scientific, Waltham, MA).

The reaction was carried out at $94{ }^{\circ} \mathrm{C}$ for $5 \mathrm{~min}$, followed by 30 cycles of $94{ }^{\circ} \mathrm{C}$ for $1 \mathrm{~min}, 56{ }^{\circ} \mathrm{C}$ for $1 \mathrm{~min}$ and $72{ }^{\circ} \mathrm{C}$ for $2 \mathrm{~min}$, and finally $72{ }^{\circ} \mathrm{C}$ for $10 \mathrm{~min}$. In the second step, a GC-PCR was performed using the second set of primers, with F984GC ( $5^{\prime}$-GC clamp AA-CGC-GAA-GAA-CCT-TAC) as the forward primer and R1378 (5'-CGG-TGT-GTA-CAA-GGC-CCG-GGA-ACG) as the reverse primer flanking the bacterial gene $16 \mathrm{~S}$ rRNA fragments to obtain a PCR-amplicon of approximately $450 \mathrm{bp}$. The master mix was prepared by adding $1 \mu \mathrm{L}$ of PCR product as a template, $5 \mathrm{X}$ GoTaq buffer, $3.75 \mathrm{mM}$ of $\mathrm{MgCl}_{2}, 0.2 \mathrm{mM}$ dNTPs, $4 \%$ acetamide (vol/vol), $0.2 \mathrm{mM}$ each of the forward and reverse primer, and 0.6 U GoTaq Flexi polymerase (Promega, Madison, WI, USA). PCR was conducted at $94{ }^{\circ} \mathrm{C}$ for 
5 min followed by 35 cycles at $94{ }^{\circ} \mathrm{C}$ for $1 \mathrm{~min}, 53^{\circ} \mathrm{C}$ for $1 \mathrm{~min}$ and $72{ }^{\circ} \mathrm{C}$ for $2 \mathrm{~min}$, final extension at $72{ }^{\circ} \mathrm{C}$ for $10 \mathrm{~min}$, and cooling to $4{ }^{\circ} \mathrm{C}$.

For amplification of the fungal internal transcribed spacer (ITS) regions, a nested PCR was conducted. First, two primers were used: ITS1-F (5'-CTT GGT CAT TTA GAG GAA GTA A) and ITS4 (5'-TCC TCC GCT TAT TGA TAT GC), flanking the ITS gene fragments to obtain a PCR-amplicon with an expected size of $450-750 \mathrm{bp}$. A reaction of $25 \mu \mathrm{L}$ volume was carried out by using $1 \mu \mathrm{L}$ of the 25 -fold diluted DNA extract, $10 \times$ TrueStart buffer, $0.2 \mu \mathrm{M}$ dNTPs, $3.75 \mathrm{mM} \mathrm{MgCl}_{2}, 2 \%$ DMSO, $0.2 \mu \mathrm{M}$ of each primer, and $0.6 \mathrm{U}$ TrueStart Taq (Fermentas). The amplification was performed at $95^{\circ} \mathrm{C}$ for $5 \mathrm{~min}$, followed by 25 cycles of $95^{\circ} \mathrm{C}$ for $30 \mathrm{~s}, 55^{\circ} \mathrm{C}$ for $30 \mathrm{~s}$ and $72{ }^{\circ} \mathrm{C}$ for $1 \mathrm{~min}$, and finally $72{ }^{\circ} \mathrm{C}$ for $10 \mathrm{~min}$. In the second PCR reaction, the primers ITS1F-GC ( $5^{\prime}$-GC clamp-CTTGGTCATTTAGAGGAAGTAA) as the forward primer and ITS2 (5'-GCTGCGTTCTTCATCGATGC) as the reverse primer, flanking the ITS2 fragments to obtain a PCR-amplicon with an expected length of approximately $250 \mathrm{bp}$ were used. The master mix was prepared by adding $1 \mu \mathrm{L}$ of the first PCR product, GoTaq buffer, $2.5 \mathrm{mM}$ of $\mathrm{MgCl}_{2}, 0.2 \mathrm{mM} \mathrm{dNTPs}$, $4 \%$ acetamide ( $\mathrm{vol} / \mathrm{vol}), 0.2 \mathrm{mM}$ each of forward and reverse primer, and $0.6 \mathrm{U}$ GoTaq Flexi polymerase (Promega). The PCR reaction was incubated at $95^{\circ} \mathrm{C}$ for $5 \mathrm{~min}$ followed by 25 cycles at $95^{\circ} \mathrm{C}$ for $30 \mathrm{~s}, 55^{\circ} \mathrm{C}$ for $30 \mathrm{~s}$ and $72{ }^{\circ} \mathrm{C}$ for $1 \mathrm{~min}$, a final extension at $72{ }^{\circ} \mathrm{C}$ for $10 \mathrm{~min}$, and cooling to $4{ }^{\circ} \mathrm{C}$.

For both PCR amplifications, $5 \mu \mathrm{L}$ of the PCR product was electrophoretically separated on a $1.5 \%$ $(w / v)$ agarose gel and electrophoresis was performed at $80 \mathrm{~V}$ for $90 \mathrm{~min}$ and visualized with $0.5 \mu \mathrm{g} / \mathrm{mL}$ ethidium bromide under ultraviolet light to test for reaction success.

To conduct the DGGE fingerprinting of bacterial and fungal gene fragments, the methodology described by [31] was followed to analyze the bacterial $16 \mathrm{~S}$ rRNA gene fragments and the fungal internal transcribed spacer (ITS) regions in the DGGE. The DGGE gels were silver stained as above-mentioned [30].

\subsubsection{DGGE Fingerprinting of Bacterial and Fungal Communities Infecting the Cysts}

For DNA extraction, ten cysts per experimental unit of the Gross Munzel location were picked from the soil extract, and soaked in $0.3 \%$ sodium hypochlorite $(\mathrm{NaOCl})$ solution for 10 min surface disinfestation. After seven washes in sterile distilled water, cysts were transferred into $1.5 \mathrm{~mL}$ tubes containing $300 \mu \mathrm{L}$ water, and crushed with a micro pestle. Using the FastDNA SPIN Kit for soil, community DNA was extracted from the cysts. The same procedures of PCR-DGGE of 16S rRNA and ITS regions with DNA extracted from soil were carried out, except for the dilution of DNA extracts, and using $3 \mu \mathrm{L}$ of the DNA suspension as a template.

\subsection{Cloning and Sequencing of ITS Genes of the Most Frequent Fungal Colonizers of H. schachtii Population at Gross Munzel}

The gene fragments of ca. 450-750 bp amplified from the common fungi infecting the cysts and detected in DGGE were cloned using the NEP PCR Cloning Kit as per the manufacturer's protocol (New England Biolabs, Ipswich, MA, USA). The generated plasmids were extracted using the Gene JET Plasmid Miniprep Kit (Thermo Fisher Scientific, Waltham, MA, USA), and submitted for sequencing using vector primers T7 or SP6.

\subsection{Data Analysis}

Non-parametric statistical analysis conducted in R software was used to estimate $H$. schachtii population densities of J2 and eggs from the field samples at one or two depths $(0-30 \mathrm{~cm}, 30-60 \mathrm{~cm}$ deep), and to compare treatment effects in the radish bioassay. The penetration ratio of $\mathrm{J} 2$ per eggs in the soil sample was calculated to determine the infection success of $H$. schachtii when derived from different field treatments. White sugar yields following fallow or oilseed radish treatments were compared. The DGGE fingerprints were analyzed by the GelCompar II 6.6 software (Applied Math, Gent, Belgium). The pairwise similarities were calculated based on the Pearson correlation coefficient. Comparisons of the similarity measures were carried out with PERMTEST [32]. The sequences of ITS fragments were analyzed using BLAST software in the search for sequence similarity in the GenBank database. 


\section{Results}

\subsection{Sampling in 2012 during Sugar Beet Cropping}

The nematode population densities from Jeinsen soil collected in spring from the two field treatments and at the different depths were similar, and ranged from medians of 8 to 27 eggs/g of soil (Table 1).

Table 1. Median numbers of Heterodera schachtii under oilseed radish and fallow at the Jeinsen location: egg population densities, penetration ratios of $\mathrm{J} 2$ in radish bioassay roots, and white sugar yields.

\begin{tabular}{cccccc}
\hline \multirow{2}{*}{ Sampling Time } & \multirow{2}{*}{ Nematode Population } & \multicolumn{2}{c}{ Oilseed Radish at } & \multicolumn{2}{c}{ Fallow at } \\
\cline { 3 - 6 } & & $\mathbf{3 0} \mathbf{~ c m}$ & $\mathbf{6 0} \mathbf{~ c m}$ & $\mathbf{3 0} \mathbf{~ c m ~}$ & $\mathbf{6 0} \mathbf{~ c m}$ \\
\hline \multirow{2}{*}{ Spring } & Eggs/g field soil & 13 & 20 & 27 & 8 \\
& Ratio of J2/eggs in radish bioassay & 0.04 & 0.04 & 0.007 & 0.007 \\
\hline \multirow{2}{*}{ Fall } & Eggs/g field soil & 17 & - & 29 & - \\
& Ratio of J2/eggs in radish bioassay & 0.03 & - & 0.06 & - \\
& White sugar yield kg/ha & \multicolumn{2}{c}{10,583} & \multicolumn{2}{c}{11,675} \\
\hline
\end{tabular}

Median values indexed with different letters were significantly different (Wilcoxon rank test, $p<0.05, n=12)$.

For each treatment, the ratio of $\mathrm{J} 2$ per egg population density for the radish bioassay data corresponding to each sample was calculated by dividing the mean number of $\mathrm{J} 2$ penetrated in the radish roots (three subsamples) to the mean number of eggs found in cysts extracted from $50 \mathrm{~g}$ soil of the three subsamples. The ratio of J2/eggs for the soil bioassay at 0-30 cm depth was significantly higher under the oilseed radish than under the fallow treatment (Figure 1). In the comparison of penetration ratios in the bioassay with extracted cysts, a higher ratio was detected in the 0-30 cm than in the 30-60 cm depth (Figure 1). In the fallow treatment at 0-30 cm depth, when field-derived cysts and cysts with organic matter treatments were added to loess in the bioassay container, ratios were higher than in the total field soil-variant, but no such difference was observed in the oilseed radish treatment (Figure 1).

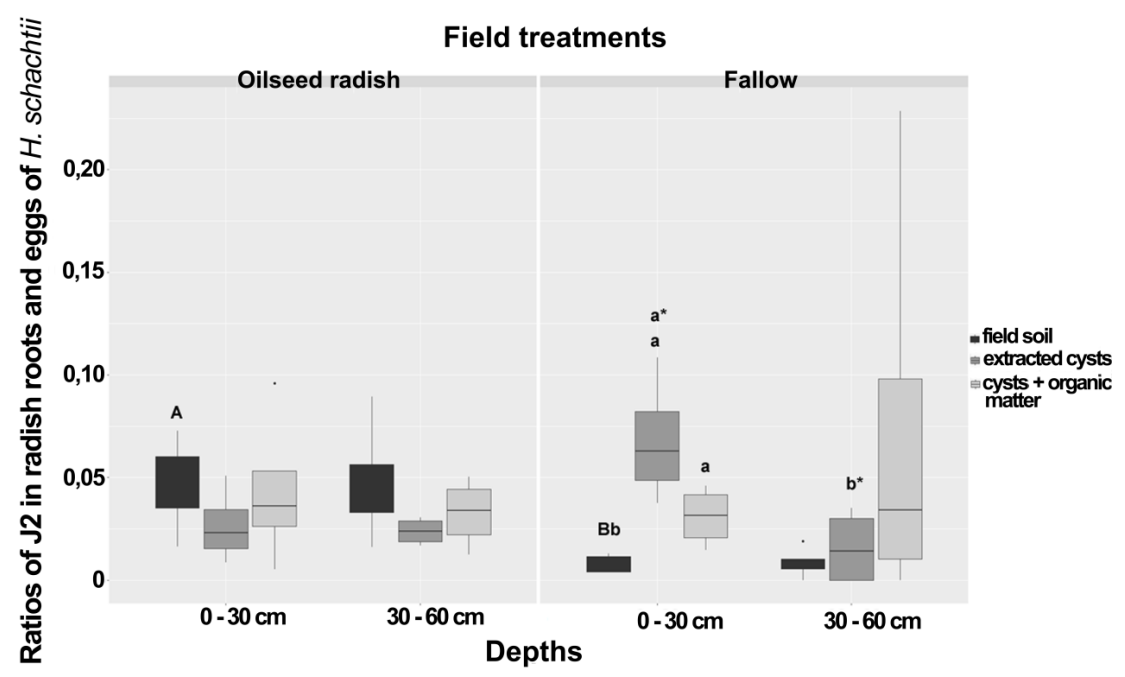

Figure 1. Ratios of J2 in radish bioassay roots and eggs of Heterodera schachtii from the spring sampling at Jeinsen in plots of oilseed radish or fallow treatment at two different depths. Boxes with the same letter, small caps = within each field treatment, small caps with asterisk = between depths within the same treatment, large caps = between groups were not significantly different (Wilcoxon rank test, $p<0.05, n=12$ ). The asterisk punctuations above the box plot charts refer to the outlier data that markedly deviated from the dataset occurring in each bioassay. The comparison between treatments was carried out at the same depth and type of bioassay. 
At harvest of the field experiment, no differences in nematode numbers at the $0-30 \mathrm{~cm}$ depth following fallow or oilseed radish treatment were detected (Table 1). Only a numerical trend of lower egg population densities following the oilseed radish (2-33 eggs/g) than after fallow (1-121 eggs/g) treatment was observed. White sugar contents were similar in both treatments $11,675 \mathrm{~kg}$ after fallow and 10,583 $\mathrm{kg} / \mathrm{ha}$ after oilseed radish (Table 1). In the radish bioassay, the variability in J2/eggs trended lower in the treatments following oilseed radish (0.01-0.08) than after fallow (0.04-0.1) (Table 1).

\subsection{Sampling Prior to Sugar Beet Cultivation at Gross Munzel}

The field egg population densities of $H$. schachtii at Gross Munzel were similar in the soil from each of the treatment areas (oilseed radish: 4-10, mustard: 3-12, fallow: 1-13 eggs/g). In the bioassay, and for each treatment, the ratio of J2/eggs corresponding to each sample was calculated by dividing the mean number of $\mathrm{J} 2$ penetrated in the radish roots (three subsamples) to the mean number of eggs found in cysts extracted from $50 \mathrm{~g}$ soil of the three subsamples. Six between-treatment and within-treatment differences in the penetration ratio were detected. The ratio of J2/eggs in the bioassay of field soil was higher under the Brassica treatments than in the fallow. This ratio was also higher in oilseed radish than in the yellow mustard and fallow treatment when comparing the results for extracted cysts and organic matter (Figure 2). Under the oilseed radish treatment, the ratio of J2/eggs in the bioassay of field soil was higher than that in the bioassay with extracted cysts (Figure 2). Under mustard treatment, the ratios in the bioassay of field soil were higher than that in the bioassay of cysts with organic matter.

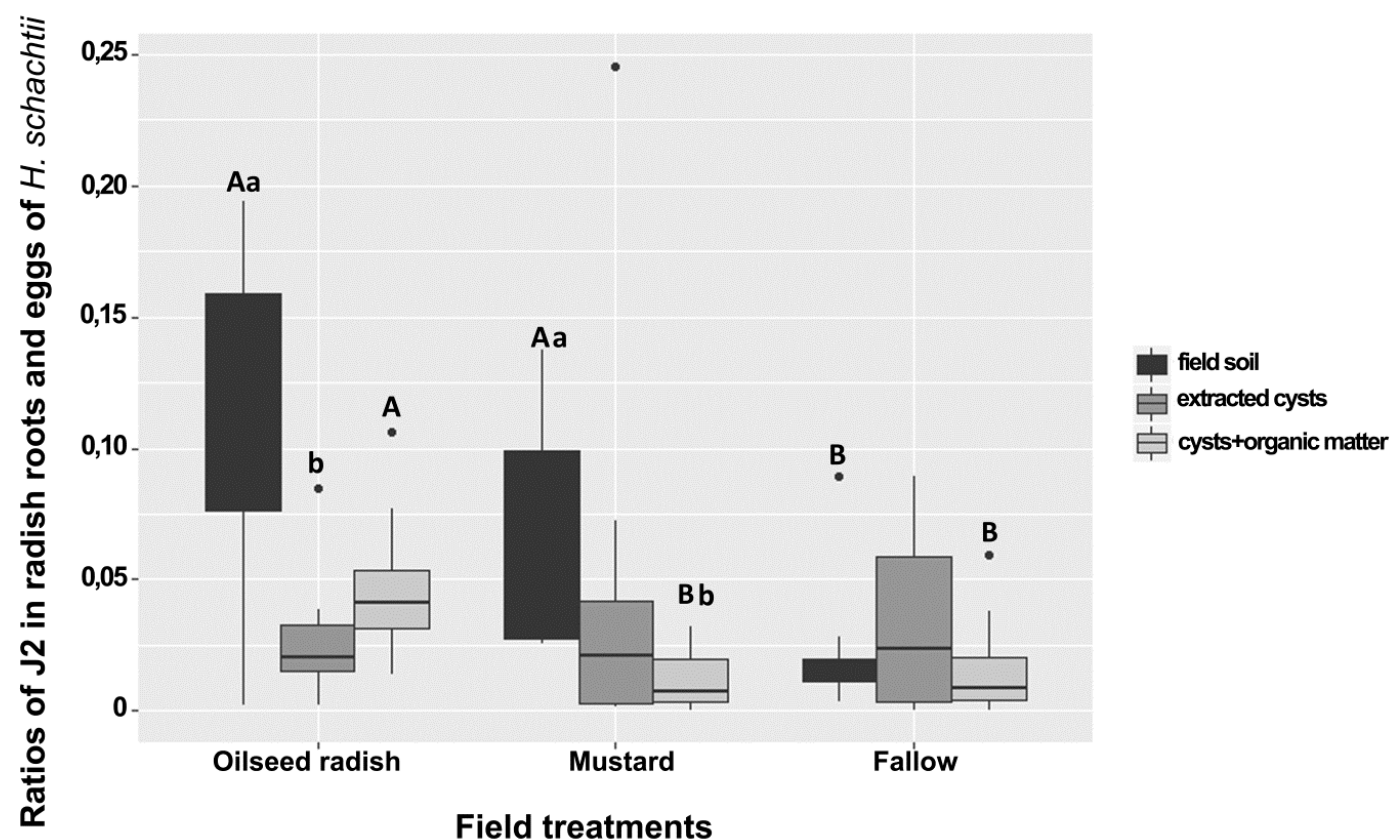

Figure 2. Ratios of $\mathrm{J} 2$ in radish bioassay roots and eggs of Heterodera schachtii from sampling at Gross Munzel in plots of oilseed radish, yellow mustard, and fallow treatment. $(a, b)$ compare the median numbers within each group. (A,B) compare the median numbers between groups (Wilcoxon rank test, $p<0.05, n=24)$. The asterisk punctuations above the box plot charts refer to the outlier data that markedly deviated from the dataset occurring in each bioassay. The comparison between treatments was carried out at the same type of bioassay.

3.3. Genetic Characterization of H. schachtii Populations from Jeinsen and Gross Munzel Using PCR-DGGE Fingerprinting of the Effector Gene vap1

The DGGE fingerprints of vap1 for the $H$. schachtii population at Jeinsen were highly similar (99\%) in the gene patterns among replicate cyst pools between the spring and harvest samples under each of the oilseed radish and fallow treatments (Figure 3). In the permutation tests based on Pearson 
correlations, vap1 patterns of the two temporal samples within each treatment were similar $(p=0.4$, $d=0.1$ under oilseed radish, $p=0.1, d=0.3$ under fallow). The $d$-value represents the difference in average gene similarity between within-treatment and between-treatment.

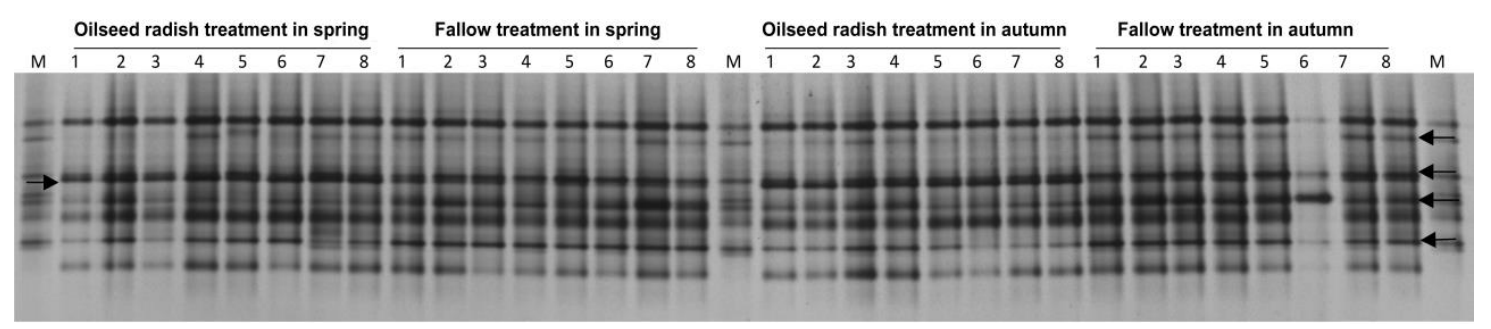

Figure 3. Jeinsen, vap1 gene-based DGGE fingerprints of $H$. schachtii population from the DNA of 60 pooled cysts per replicate sample (the number above each lane refers to the replicate number for each treatment), and electrophoretic separation by DGGE. M: marker of cloned vap1 variants. The arrows indicate to the different vap1 bands in their intensities between oilseed radish and fallow treatments.

The vap 1 patterns revealed $94 \%$ similarity between the oilseed radish and fallow treatments. Nonetheless, the permutation test showed a significant difference between the vap1 patterns of the two treatments $(p<0.001, d=6$ ). In the DGGE profiles, the intensity of four vap1 bands was higher for fallow treatment than for the oilseed radish treatment, while the intensity of one band was higher for oilseed radish than for the fallow treatment (Figure 3).

The vap1 fingerprints of the Gross Munzel populations at the level of pooled cysts were derived by PCR amplification of vap1 variants from the DNA of 10 pooled cysts per replicate and electrophoretic separation by DGGE. The vap1 patterns of the pooled cysts under the three treatments were similar, but one band was more frequent in the oilseed radish than in the mustard and the fallow treatments. In the permutation test of pairwise similarities, the vap1 patterns between oilseed radish and each of mustard and fallow treatments were significantly different (permutation test on Pearson correlations, $p=0.001, d=4)$ (Figure 4$)$.

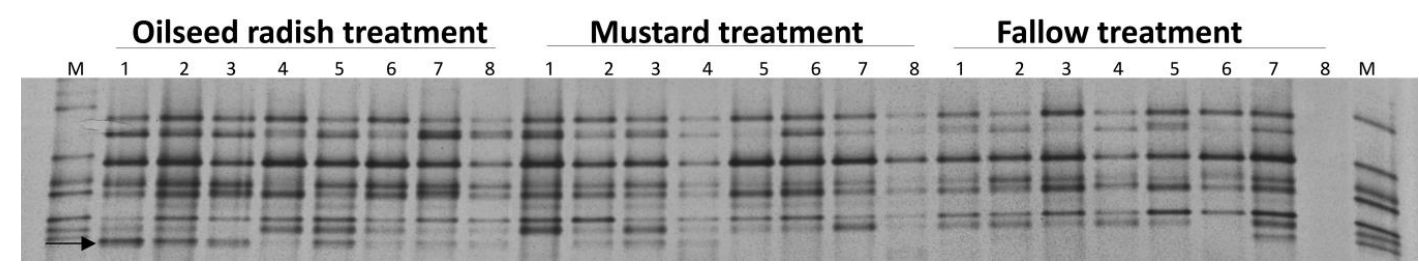

Figure 4. Gross Munzel, vap1 gene-based DGGE fingerprints of Heterodera schachtii population from DNA of 10 pooled cysts per replicate sample (the number above each lane refers to the replicate number for each treatment), and electrophoretic separation by DGGE. M: marker of cloned vap1 variants. The arrow indicates the vap 1 band whose intensity under oilseed radish was higher than mustard and fallow treatment.

\subsection{Analyzing the Soil Bacterial and Fungal Communities at Gross Munzel}

For the Gross Munzel location, DGGE fingerprinting of 16S rRNA gene fragments was conducted to analyze the effect of cover pre-crops on the bacterial community in soil during the following sugar beet cultivation. Each lane presented the 16S rRNA fragments amplified by PCR from the total community DNA of $0.5 \mathrm{~g}$ soil of one replicate sample per experimental unit. The $16 \mathrm{~S}$ rRNA patterns of samples differed significantly between the three treatments (Table 2). 
Table 2. $p$ - and $d$-value resulting from the permutation tests to compare the average similarities of $16 \mathrm{~S}$ rRNA and ITS gene profiles derived respectively from the DGGE fingerprints of the soil bacteria and fungi at the Gross Munzel location ( $p$ - and $d$-value based on the Pearson correlation similarities).

\begin{tabular}{cccc}
\hline DGGE Fingerprints of Soil Microbes & Compared Treatments & $\boldsymbol{p}$-Value & $\boldsymbol{d}$-Value \\
\hline \multirow{3}{*}{ Soil bacteria } & Oilseed radish vs. mustard & 0.007 & 1 \\
& Oilseed radish vs. fallow & 0.004 & 2 \\
& Mustard vs. fallow & 0.001 & 3 \\
\hline \multirow{2}{*}{ Soil fungi } & Oilseed radish vs. mustard & 0.001 & 5 \\
& Oilseed radish vs. fallow & 0.001 & 6 \\
& Mustard vs. fallow & 0.001 & 3 \\
\hline
\end{tabular}

DGGE fingerprinting of ITS fragments was conducted to analyze the fungal communities from soil samples of the three soil pre-treatments (oilseed radish, mustard, and fallow). Single lanes represented the ITS fragments amplified by PCR from the total community DNA of $0.5 \mathrm{~g}$ soil per experimental unit. The ITS patterns of samples differed significantly between the three treatments (Table 2).

\subsection{Bacterial and Fungal Communities in Cysts of H. schachtii at Gross Munzel}

The DGGE fingerprints of 10 pooled cysts per replicate sample were highly variable within the treatment. Each replicate sample had a unique 16S rRNA profile. The bacterial communities in cysts from fallow soil pre-treatment differed significantly from those of the oilseed radish and mustard treatments (permutation test on Pearson correlations, $p=0.001, d=7$ ) (Figure 5). The 16S rRNA patterns of pooled cysts were similar in the oilseed radish and mustard treatment.

\section{Bacterial isolates infecting cysts under}

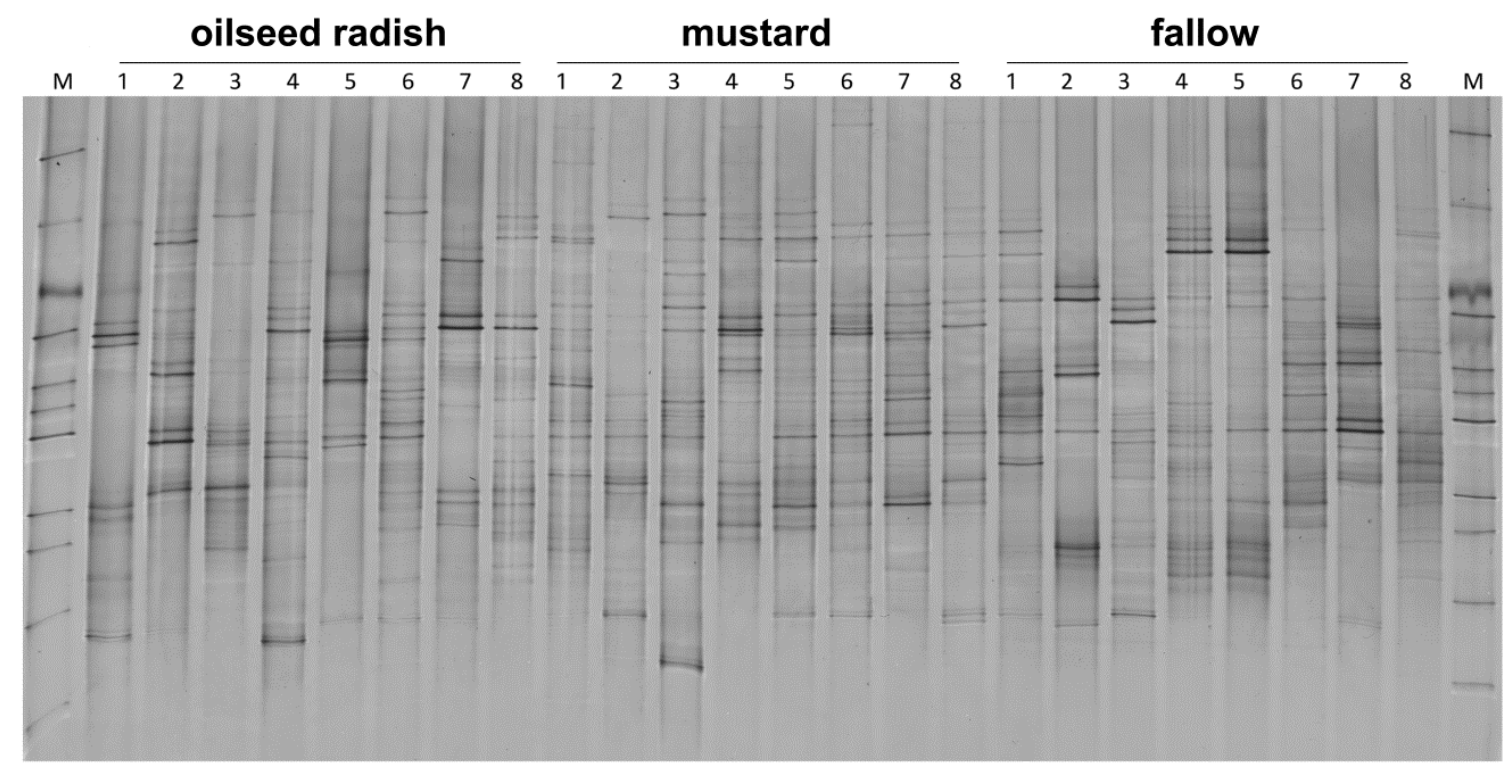

Figure 5. Gross Munzel, DGGE fingerprints of $16 \mathrm{~S}$ rRNA gene fragments amplified from the DNA of 10 pooled cysts per replicate sample (the number above each lane refers to the replicate number for each treatment) from three cover crop treatments in the year prior to the sugar beet production. M: Marker including the $16 \mathrm{~S}$ rRNA fragments of bacterial isolates.

The ITS fragments were PCR-amplified from the DNA of 10 pooled cysts per replicate sample and separated in DGGE (Figure 6). Seventeen out of the twenty detected ITS patterns in DGGE were distinct and highly variable. The ITS patterns of samples differed significantly only between oilseed radish and fallow treatment (permutation test on Pearson correlations, $p=0.02, d=6$ ) (Figure 6). Two bands detected in the gene pattern of sample 6 from the oilseed radish did not appear in the gene 
patterns of samples from the fallow treatment, while other bands were more frequent in the patterns under fallow than in the oilseed radish treatment.

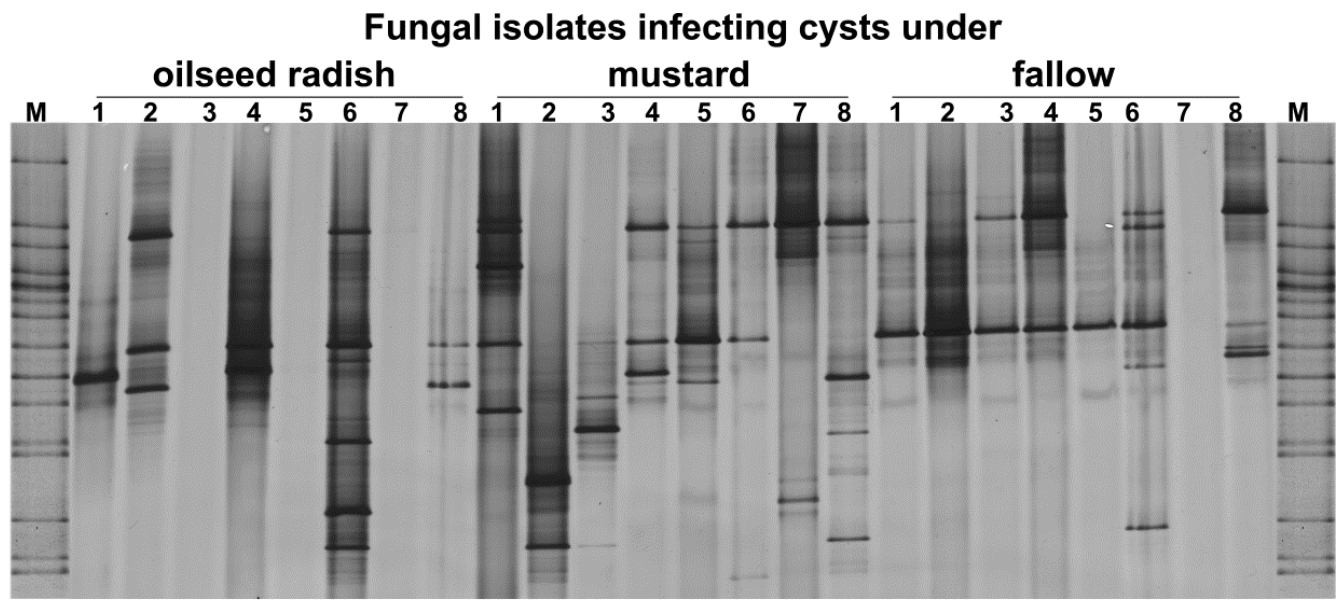

Figure 6. Gross Munzel, DGGE fingerprints of ITS gene fragments amplified from 10 pooled cysts per replicate sample (the number above each lane refers to the replicate number for each treatment) from the soil of three cover crop treatments in the year prior to the sugar beet production. M: Marker including the ITS fragments of fungal isolates.

Two bands were the most frequent in the ITS patterns of fungi colonizing the cysts of $H$. schachtii at Gross Munzel. To identify those two ITS bands, the process of gene cloning and sequencing was conducted. In the ITS-DGGE fingerprints, the upper bands (clones 1, 4, 5, and 6) were identical in DNA sequence to an endophytic isolate of Exophiala salmonis (GenBank accession: GU586858.1). The lower bands (clones 2,3, and 7) were 99\% identical to Pochonia chlamydosporia (GenBank accession AY912487.1) (Figure 7).

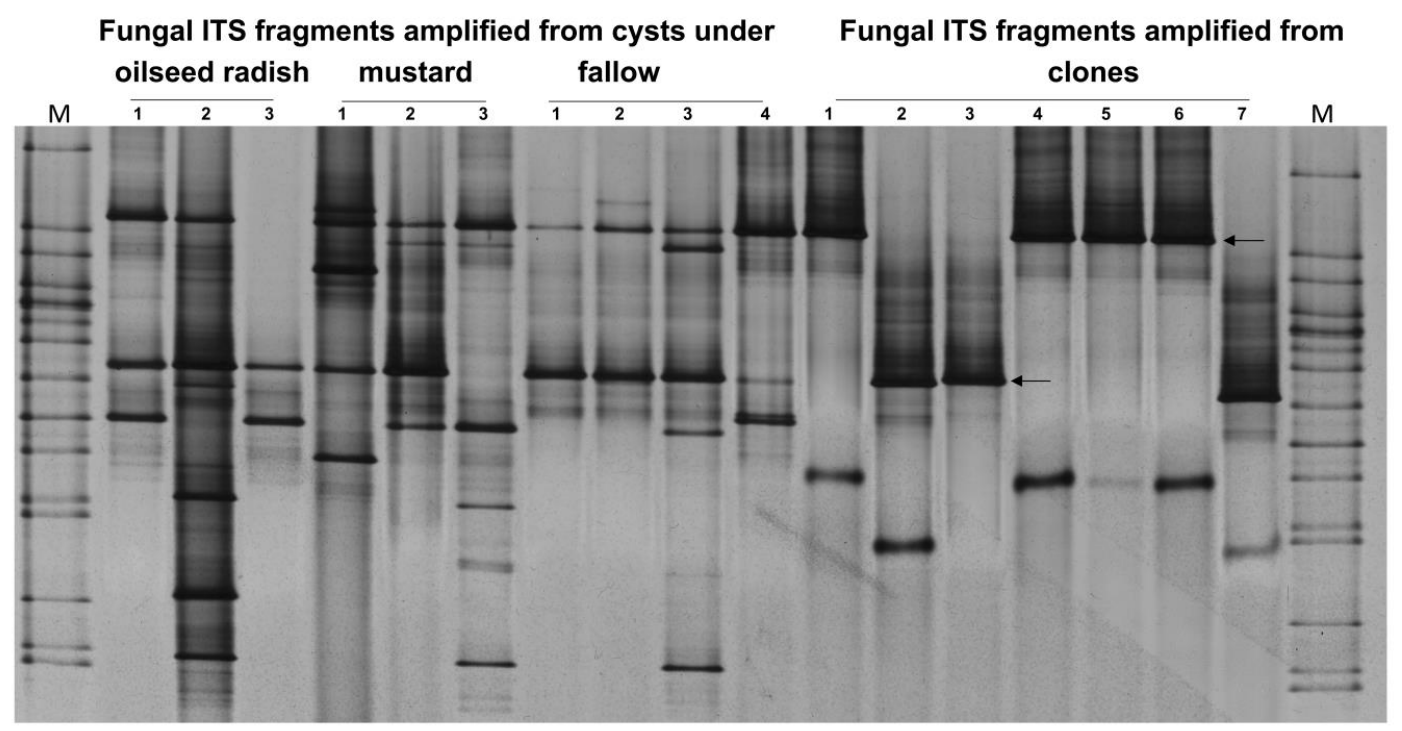

Figure 7. Gross Munzel, ITS-DGGE fingerprints for the most frequent colonizers of $H$. schachtii population at Gross Munzel as indicated by two arrows. The patterns of ITS fragments amplified from the DNA of the pooled cysts under the three treatments were used as references in DGGE to confirm that the cloned ITS fragments were identical to the most frequent ITS fragments required to be sequenced. M: Marker including the ITS fragments of fungal isolates. 


\section{Discussion}

In the current project, cover cropping with $H$. schachtii-resistant oilseed radish and mustard led to cysts with varying microbial communities and with a change in the virulence gene vap1. Colonization of the cysts with fungal egg parasites was reduced after culture of the cover crops when compared to the fallow controls. This confirmed findings by Nicolay et al. (1990) [20], who found reduced colonization of nematode eggs in a baiting assay following an oilseed radish cover crop. Changes in the virulence gene could impact the ability of $H$. schachtii to infect sugar beet roots. Due to the lack of reproductive opportunity during the stubble treatment phase, most encysted eggs in the fallow treatment were probably at least one year older than the newly formed eggs in the cover crop treatment. Nematode-resistant plants frequently allow for some reproduction of the parasite, which should result in some proportion of the eggs from oilseed radish to be freshly produced. Such encysted eggs in the radish bioassay were hypothetically newly formed eggs on the cover crop roots, and may reflect the selection pressure exerted by the radish cover crop genetics. Such selection pressure has been reported previously when resistant cultivars of oilseed radish caused genetic changes in the nematode population genetic structure [22]. Sustainable nematode suppression by cover crops may depend on differences in resistance systems in cover crops and sugar beets [32]. Possible effects of selection pressure could not be determined because the pre-cover crop populations were not characterized.

Cover cropping affected the microbial communities colonizing $H$. schachtii cysts. The DGGE profiles for bacterial communities infecting the cysts of $H$. schachtii populations at Gross Munzel differed between oilseed radish vs. fallow and mustard vs. fallow treatments. Similar differences were found in the fungal communities infecting the cysts between oilseed radish and fallow treatments. There was a non-significant trend in the profiles of fungi for mustard compared to fallow. Plant root exudates in the cover crop plots could have impacted the microbial soil communities [33]. As shown in the analysis of the 16S rRNA gene and ITS based DGGE profiles, the soil bacterial and fungal communities were significantly different between oilseed radish vs. fallow, oilseed radish vs. mustard, and mustard vs. fallow treatments. These differences might have led to differences in bacteria and fungi infecting the cysts between those treatments. Thus, the differences in the microbial communities infecting $H$. schachtii populations corresponded to the differences in the soil microbial communities.

The access of microorganisms to the encysted eggs could occur in several ways. During the movement of J2 in the soil, microbes may attach to the nematode cuticle, later infecting the eggs of nematodes [14]. In addition, the endophytic fungi characterized as antagonistic to nematodes like Pochonia chlamydosporia [34] infect the host plant and then access the nematode eggs while growing in the plant root. The microbial infection of the encysted eggs can also commence after the immature female nematodes become exposed to soil on the plant roots [14]. In all modes of microbial infection of the nematodes, the soil is considered to be the source of microbes, and changes in the soil microbial communities may lead to changes in the microbes infecting the nematodes.

An additional factor that could affect the microbial communities among nematode populations is the nematode surface phenotype. Heritable changes in surface properties affected the bacterial adhesion to the cuticle of Meloidogyne spp. and the nematode Caenorhabditis elegans [35,36]. Analysis of genes determining the characteristics of the nematode cuticle is required to reveal the reason for changes in the microbial communities infecting the nematodes. However, in the present study at the Gross Munzel location, the vap1 gene-based DGGE profiles of the population of $H$. schachtii originating from oilseed radish plots were different to those derived from mustard and fallow areas. Differences in vap1 genes corresponded with the differences in the bacterial and fungal communities infecting cysts for those population pairs. However, the microbial communities infecting the cysts were different between mustard vs. fallow treatments while their vap1 patterns were highly similar. A passive mixing of soil between mustard and fallow treatment areas by soil tillage may have contributed to these two homogenous populations. The plant root exudates may correlate to the differences in the microbes of the soil and within the nematode cysts between mustard and fallow areas where the soil samples were drawn during plant growth. As a parasitism gene, vap1 may not have contributed to differences in the 
microbial colonization of the nematodes as it is an indicator for genetic differences after the cover crop phase. The differences in vap1 patterns could be one reason for the differences in the virulence between populations at each of the Gross Munzel and Jeinsen locations, especially because this gene plays an important role in the parasitism process by modulating the plant defense [37].

The differences of J2/eggs in the bioassays between oilseed radish vs. fallow, and mustard vs. fallow treatments for the Gross Munzel population could be affected by the differences in the bacterial and fungal communities infecting the cysts among the three treatments. In an analysis of the fungal communities infecting the cysts, two ITS bands representing the isolates of Pochonia chlamydosporia and Exophiala salmonis were more frequent in the DGGE patterns of fallow than in oilseed radish and mustard. The fungal parasite Pochonia chlamydosporia is one of the few significant pathogens of cyst nematodes [14], and the isolate of Exophiala spp. is one of the most frequent fungi isolated from infected eggs of the potato cyst nematode Globodera rostochiensis and soybean cyst nematode Heterodera glycines $[38,39]$. Colonization with these fungi may decrease the proportion of healthy eggs. The egg population densities did not differ between the two treatments, but may be the proportion of unhealthy eggs was different between treatments, thus the number of J2 that penetrated the roots was impacted.

At both locations, the ratios of J2/eggs in the soil bioassays were higher in plots from oilseed radish than the fallow treatment. It is known that the penetration speed of $H$. schachtii juveniles in the plant roots is an indicator for the virulence of the population, and the differences in this speed are related to the genetic differences present between populations [40]. Interestingly, the DGGE patterns of the parasitism gene vap 1 for the pooled cysts were different between populations from oilseed radish and fallow. Therefore, this genetic difference may have contributed to the measured differences.

At Gross Munzel under oilseed radish, the ratio of J2/eggs was higher in the soil bioassay than for the cysts in loess, and under mustard, it was also higher in the soil bioassay than for cysts and organic matter in loess. Perhaps the root exudates under field conditions stimulated the hatch of the J2, so that the bioassay also measured those nematodes present in the soil. Compounds released by plants into the soil could attract nematodes to the roots [41]. Such differences in the ratio of J2/eggs between the three types of radish bioassay were not observed at Jeinsen under the oilseed radish treatment. This could be based on the fact that no plants were established in the Jeinsen field at the sampling time, and there were minimal root exudates that could have influenced the nematode hatch.

At Jeinsen in spring, the ratio of J2/eggs for the soil bioassay was less than for the bioassays of cysts in loess and cysts with organic matter in loess. The soil may have reduced nematode movement, either physically or biologically. Our experiments did not allow us to determine this. It is known that the loess substrate is less aggregated than the field soil, which may have facilitated the easier movement of nematode juveniles [42].

At the Jeinsen location, the ratio of J2/eggs in the bioassays conducted with extracted cysts was higher at $0-30 \mathrm{~cm}$ than at $30-60 \mathrm{~cm}$ depths under fallow treatment. Similar results were reported previously in a study of the fallow period in a sugar beet field in California [8]. In that case, the egg parasitism rate of $H$. schachtii at the $0-30 \mathrm{~cm}$ soil depth was less than at $30-60 \mathrm{~cm}$. Similar differences in soil moisture between the depths were hypothetically affecting differences in the activity of egg parasites [8]. Similar concepts could explain the difference in the penetration ratios in our study. Soil temperature, soil texture, and plant growth can affect the vertical distribution of different species of plant-parasitic nematodes, e.g., Belonolaimus longicaudatus, Pratylenchus brachyurus, and Trichodorus christiei, in the soil [43]. In the current study, soil samples were taken when there was no plant growth in the soil, reducing the plant effect on the abiotic factors that could influence depth stratification.

In conclusion, differences in bacteria and fungi infecting the cysts under the treatments of oilseed radish and mustard could have affected the differences in the J2/eggs of the radish bioassays. There was also correlative evidence that the population differences in the vap1 variants may have contributed to these differences. Cover cropping with resistant Brassica lines in sugar beet rotations has a long track record of success. In this study, changes in microbial communities within the cysts, and virulence 
pattern of the nematode, potentially negative for nematode suppression, were measured but other aspects of this cover cropping may be more important for its sustainability.

Author Contributions: Funding acquisition, H.H.; Investigation, R.H.N., H.H., and A.W.; Methodology, H.H. and A.W.; Supervision, H.H. and A.W.; Writing-Original draft, R.H.N.; Writing-Review \& editing, H.H. and A.W.

Funding: This research was funded by Deutsche Forschungsgemeinschaft grant number HE6957/1-1.

Acknowledgments: The authors thank Bernhard Werner (LWK Lower Saxonia) for access to the field sites, the members of the Institute of Plant Protection in Field Crops, Julius Kühn-Institut, Braunschweig (P. Zwerger) for their assistance, and the German Academic Exchange Service (DAAD) for their support of the first author during this study.

Conflicts of Interest: The authors declare no conflict of interest.

\section{References}

1. Hallmann, J.; Daub, M.; Grundler, F.; Westphal, A. 150 Jahre Heterodera schachtii: Ein Überblick der Frühen Arbeiten. J. Kulturpflanzen 2009, 61, 429-439.

2. Schlang, J. The Biological Control of White Beet Cyst Nematodes Heterodera schachtii by Resistant Catch Crops. In Proceedings of the 52nd Winter Congress of the International Institute for Sugar Beet Research, Brussels, Belgium, 15-16 February 1989.

3. Curto, G. Sustainable Methods for Management of Cyst Nematodes. In Integrated Management and Biocontrol of Vegetable and Grain Crops Nematodes; Chapter 11; Ciancio, A., Mukerji, K.G., Eds.; Springer: Dordrecht, The Netherlands, 2008; pp. 221-237, ISBN 9781402060625.

4. Koch, D.W.; Gray, F.A. Nematode-Resistant Oil Radish for Heterodera schachtii Control II. Sugerbeet-Dry Bean-Corn Rotations. J. Sugar Beet Res. 1998, 35, 63-75. [CrossRef]

5. Dewar, A.M. Beet Cyst Nematodes-A Peril of the Soil. Br. Sugar Beet Rev. 2005, 73, 40-46.

6. Müller, J. New Pathotypes of the Beet Cyst Nematode (Heterodera schachtii) Differentiated on Alien Genes for Resistance in Beet (Beta vulgaris). Fundam. Appl. Nematol. 1998, 21, 519-526.

7. Westphal, A.; Pyrowolakis, A.; Sikora, R.A.; Becker, J.O. Soil Suppressiveness Against Heterodera Schachtii in California Cropping Areas. Nematropica 2011, 41, 161-171.

8. Roberts, P.A.; Thomason, I.J.; McKinney, H.E. Influence of Nonhosts, Crucifers, and Fungal Parasites on Field Populations of Heterodera schochtii. J. Nematol. 1981, 13, 164-171.

9. Nigh, E.A.; Thomason, I.J.; van Gundy, S.D. Identification and Distribution of Fungal Parasites of Heterodera schachtii Eggs in California. Phytopathology 1980, 70, 884-889. [CrossRef]

10. Bird, A.F.; Zuckerman, B.M. Studies on the Surface Coat (glycocalyx) of the Dauer Larva of Anguina agrostis. Int. J. Parasitol. 1989, 19, 235-240. [CrossRef]

11. Westphal, A.; Becker, J.O. Biological Suppression and Natural Population Decline of Heterodera schachtii in a California Field. Phytopathology 1999, 89, 434-440. [CrossRef]

12. Westphal, A.; Becker, J.O. Transfer of Biological Soil Suppressiveness against Heterodera schachtii. Phytopathology 2000, 90, 401-406. [CrossRef]

13. Westphal, A.; Becker, J.O. Components of Soil Suppressiveness against Heterodera schachtii. Soil Biol. Biochem. 2001, 33, 9-16. [CrossRef]

14. Stirling, G.R. Biological Control of Plant Parasitic Nematodes, 2nd ed.; CAB International: Wallingford, UK, 2014; ISBN 1780644159.

15. Kerry, B.R.; Anderson, S. Nematophthora gynophila och Verticillium chlamydosporium Svampparasiter på Cystnematoder, Vanliga i Svenska Jordar Reed Förekomst av Stråsäides-Cystnematoder. Vaxtskyddsnotiser 1984, 47, 5-6.

16. Jones, F.G.W. Soil Populations of Beet Eelworm (Heterodera schachtii Schm.) in Relation to Cropping. Ann. Appl. Biol. 1945, 32, 351-380. [CrossRef]

17. Westphal, A.; Becker, J.O. Soil Suppressiveness to Heterodera schachtii under Different Cropping Sequences. Nematology 2001, 3, 551-558. [CrossRef]

18. Oostendorp, M.; Dickson, D.W.; Mitchell, D.J. Population Development of Pasteuria penetrans on Meloidogyne arenaria. J. Nematol. 1991, 23, 58-64. [PubMed] 
19. Chen, S.; Dickson, D.W.; Kimbrough, J.W.; McSorley, R.; Mitchell, D.J. Fungi Associated with Females and Cysts of Heterodera glycines in a Florida Soybean Field. J. Nematol. 1994, 26, 296-303. [PubMed]

20. Nicolay, R.; Sikora, R.A.; Weltzien, H.C. Influence of Green Manure, Straw and Compost on the Activity of Fungal Egg Parasites of Heterodera schachtii Schmidt. J. Plant Dis. Prot. 1990, 97, 470-483.

21. Timper, P. Conserving and Enhancing Biological Control of Nematodes. J. Nematol. 2014, 46, 75-89.

22. Kaplan, M.; Caswell-Chen, E.P.; Williamson, V.M. Assessment of Host-Induced Selection on Three Geographic Isolates of Heterodera schachtii Using RAPD and AFLP Markers. Phytopathology 1999, 89, 68-73. [CrossRef]

23. Nuaima, R.H.; Roeb, J.; Hallmann, J.; Daub, M.; Otte, S.; Heuer, H. Effector Gene vap1 Based DGGE Fingerprinting to Assess Variation Within and Among Heterodera schachtii Populations. J. Nematol. 2018, 50, 517-528. [CrossRef]

24. Müller, J. Detection of pathotypes by assessing the virulence of Heterodera schachtii populations. Nematologica 1992, 38, 50-64. [CrossRef]

25. Nuaima, R.H.; Roeb, J.; Hallmann, J.; Daub, M.; Heuer, H. Significant Genetic Differences among Heterodera schachtii Populations within and among Sugar Beet Production Areas. Nematology 2019, 1-13. [CrossRef]

26. Müller, J. Ein Verbessertes Extraktionsverfahren für Heterodera schachtii. Nachrichtenblatt des deutschen Pflanzenschutzdienstes 1980, 32, 21-24.

27. Westphal, A.; Becker, J.O. Impact of Soil Suppressiveness on Various Population Densities of Heterodera schachtii. Ann. Appl. Biol. 2001, 138, 371-376. [CrossRef]

28. Meinecke, A.; Hermann, A.; Westphal, A. Using a Selective Fast Turn-around Bioassay for Population Density Determination of Heterodera schachtii. Nematology 2013, 15, 809-819. [CrossRef]

29. Heuer, H.; Wieland, G.; Schönfeld, J.; Schönwälder, A.; Gomes, N.C.M.; Smalla, K. Bacterial Community Profiling Using DGGE or TGGE Analysis. In Environmental Molecular Microbiology: Protocols and Applications; Rochelle, P.A., Ed.; Horizon Scientific Press: Wymondham, UK, 2001; pp. 177-190, ISBN 1898486298.

30. Weinert, N.; Meincke, R.; Gottwald, C.; Heuer, H.; Gomes, N.C.; Schloter, M.; Berg, G.; Smalla, K. Rhizosphere Communities of Genetically Modified Zeaxanthin-Accumulating Potato Plants and Their Parent Cultivar Differ Less than Those of Different Potato Cultivars. Appl. Environ. Microbiol. 2009, 75, 3859-3865. [CrossRef] [PubMed]

31. Kropf, S.; Heuer, H.; Grüning, M.; Smalla, K. Significance Test for Comparing Complex Microbial Community Fingerprints Using Pairwise Similarity Measures. J. Microbiol. Methods 2004, 57, 187-195. [CrossRef]

32. Budahn, H.; Schrader, O.; Peterka, H. Development of a Complete Set of Disomic Rape-radish Chromosome-addition Lines. Euphytica 2008, 162, 117-128. [CrossRef]

33. Kawasaki, A.; Donn, S.; Ryan, P.R.; Mathesius, U.; Devilla, R.; Jones, A.; Watt, M. Microbiome and Exudates of the Root and Rhizosphere of Brachypodium distachyon, a Model for Wheat. PLoS ONE 2016, 11, e0164533. [CrossRef]

34. Schouten, A. Mechanisms Involved in Nematode Control by Endophytic Fungi. Annu. Rev. Phytopathol. 2016, 54, 121-142. [CrossRef]

35. Davies, K.G.; Rowe, J.A.; Williamson, V.M. Inter- and Intra-specific Cuticle Variation Between Amphimictic and Parthenogenetic Species of Root-knot Nematode (Meloidogyne spp.) as Revealed by a Bacterial Parasite (Pasteuria penetrans). Int. J. Parasitol. 2008, 38, 851-859. [CrossRef] [PubMed]

36. Gravato-Nobre, M.J.; Stroud, D.; O’Rourke, D.; Darby, C.; Hodgkin, J. Glycosylation Genes Expressed in Seam Cells Determine Complex Surface Properties and Bacterial Adhesion to the Cuticle of Caenorhabditis elegans. Genetics 2011, 187, 141-155. [CrossRef] [PubMed]

37. Lozano-Torres, J.L.; Wilbers, R.H.P.; Warmerdam, S.; Finkers-Tomczak, A.; Diaz-Granados, A.; van Schaik, C.C.; Helder, J.; Bakker, J.; Goverse, A.; Schots, A.; et al. Apoplastic Venom Allergen-like Proteins of Cyst Nematodes Modulate the Activation of Basal Plant Innate Immunity by Cell Surface Receptors. PLoS Pathog. 2014, 10, e1004569. [CrossRef] [PubMed]

38. Dackman, C. Fungal Parasites of the Potato Cyst Nematode Globodera rostochiensis: Isolation and Reinfection. J. Nematol. 1990, 22, 594-597. [PubMed]

39. Chen, S.Y.; Dickson, D.W.; Mitchell, D.J. Pathogenicity of Fungi to Eggs of Heterodera glycines. J. Nematol. 1996, 28, 148-158. [PubMed]

40. Griffin, G.D. Pathological Differences in Heterodera schachtii Populations. J. Nematol. 1981, 13, $191-195$.

41. Li, T.; Wang, H.; Xia, X.; Cao, S.; Yao, J.; Zhang, L. Inhibitory Effects of Components from Root Exudates of Welsh Onion Against Root Knot Nematodes. PLoS ONE 2018, 13. [CrossRef] 
42. Jones, F.G.W.; Larbey, D.W.; Parrott, D.M. The Influence of Soil Structure and Moisture on Nematodes, Especially Xiphinema, Longidorus, Trichodorus and Heterodera spp. Soil Biol. Biochem. 1969, 1, 153-165. [CrossRef]

43. Brodie, B.B. Vertical Distribution of Three Nematode Species in Relation to Certain Soil Properties. J. Nematol. $1975,8,243-247$. article distributed under the terms and conditions of the Creative Commons Attribution (CC BY) license (http://creativecommons.org/licenses/by/4.0/). 